\title{
PRESÍDIO-EMPRESA E ENCARCERAMENTO EM MASSA: UMA DENÚNCIA AO ATUAL REGIME DE COMPLEXOS INDUSTRIAIS PENAIS E A TRANSFORMAÇÃO DA MISÉRIA EM NÉGOCIO
}

\author{
PRESIDIO-EMPRESA Y ENCARCELAMIENTO MASIVO: \\ UNA DENUNCIA AL ACTUAL RÉGIMEN DE COMPLEJOS INDUSTRIALES \\ PENALES Y LA TRANSFORMACIÓN DE LA MISERIA EN NÉGOCIO
}

COMPANY PRESENTATION AND MASS ACQUISITION: A COMPLAINT TO THE CURRENT REGIME OF INDUSTRIAL PENAL COMPLEXES AND THE TRANSFORMATION OF THE MISERY IN BUSINESS

Vinicius Agueda VALENTIM ${ }^{1}$

RESUMO: O trabalho a seguir é fruto de profunda introspecção sobre o tema dos presídios. É preciso dizer que a abordagem escolhida destoa das análises estritamente jurídicas - as quais já contam com extensa literatura - ao mesmo tempo em que realiza um convite para pensar sobre os fatores econômicos e políticos que engendram a realidade. Deste modo, será discutido o conceito de ressocialização enquanto eco de um Mito que permite o controle social pelo medo, ipsis letteris acontecia nas monarquias absolutistas. Para além do castigo em si, que de toda a maneira não deixará de ser apreciado, será oferecida ênfase à formação ideológica do cárcere e as suas implicações na sociedade contemporânea. Após caminhar pela subjetividade dos sujeitos, será aventada a hipótese que reside na mercadorização de presos e na subsequente formação de um mercado para o interesse privado. Em última instância, a presente denúncia não deixará de indicar que a realidade particular brasileira não está descolada dos movimentos gerais, realizando paralelo com os Estados Unidos.

PALAVRAS-CHAVE: Presídios. Ressocialização. Neoliberalismo. Privatização. Mercadorização.

RESUMEN: El trabajo a seguir es fruto de profunda introspección sobre el tema de los presidios. Es preciso decir que el enfoque escogido desto de los análisis estrictamente jurídicos - que ya cuentan con extensa literatura- al mismo tiempo que realiza una invitación para pensar sobre los factores económicos y políticos que engendran la realidad. De este modo, discutir el concepto de resocialización como eco de un Mito que permite el control social por el miedo, ipsis letteris sucedía en las monarquías absolutistas. Además del castigo en sí, que de cualquier manera no dejará de ser apreciado, se ofrecerá énfasis a la formación ideológica de la cárcel y sus implicaciones en la sociedad contemporánea. Después de caminar por la subjetividad de los sujetos, se aventurará la hipótesis que reside en la mercadería de presos y en la subsiguiente formación de un mercado para el interés privado. En última instancia, la presente denuncia no

${ }^{1}$ Universidade Federal do Rio de Janeiro (UFRJ) Rio de Janeiro - RJ - Brasil. Bacharel em Ciência Política. ORCID: <http://orcid.org/0000-0002-7653-8582>.E-mail: vinicius.valentim@ hotmail.com. 
dejará de indicar que la realidad particular brasileña no está descolgada de los movimientos generales, realizando paralelo con los Estados Unidos.

PALABRAS CLAVE: Presídios. Resocialización. El neoliberalismo. La privatización. Mercantilización.

ABSTRACT: The following work is the fruit of deep introspection on the subject of prisons. It is necessary to say that the chosen approach is from the strictly legal analyzes - which already have an extensive literature - at the same time as it invites us to think about the economic and political factors that engender reality. In this way, I propose to discuss the concept of resocialization as an echo of a Myth that allows social control through fear, ipsis letteris happened in the absolutist monarchies. Beyond the punishment itself, which in any case will be appreciated, emphasis will be placed on the ideological formation of the prison and its implications on contemporary society. Following the subjectivity of the subjects, the hypothesis that lies in the commercialization of prisoners and the subsequent formation of a market for private interest will be proposed. Ultimately, this denunciation will not fail to indicate that the particular Brazilian reality is not detached from the general movements, in parallel with the United States.

KEYWORDS: Prisons. Resocialization. Neoliberalism. Privatization. Merchandising.

\section{Introdução}

O principal objetivo do presente artigo é discutir o mito da ressocialização e, de modo mais específico, da formação ideológica da forma-presídio, e sua importância para a construção da subjetividade dos sujeitos - para além da violência direta, observada nos espaços do cárcere.

Dessa maneira, nos propomos a discutir a mercadorização dos encarcerados e, por conseguinte, a arquitetura de um verdadeiro nicho mercadológico para os interesses privados no campo da segurança. Ademais, pontuo aqui o caráter de denúncia do presente estudo que busca, sobretudo, se distanciar da literatura corrente e do terreno jurídico, embora este seja devidamente contemplado. De forma que, este trabalho é direcionado por importantes conceitos de Gramsci, os quais pretendem trazer ao estudo maior complexidade política.

Dividimos o artigo da seguinte maneira: No item 1.1 tratamos da forma presídio e discutimos a dialética que interpela as prisões, de tal modo que fazemos um breve, porém necessário, resgate histórico que envolve o tema do cárcere, em diferentes países do mundo. Nessa sequência, no item 1.2 debatemos a questão da ressocialização e a incompatibilidade de sua forma, no que se refere ao próprio mito ressocializador e à estrutura insuficiente do Direito Penal. 
No item 2, trazemos a discussão da espetacularização do cárcere e o Império da imagem, onde há o esforço em abordar o tema dos presídios sob a ótica do Espetáculo, de maneira que seja discutida a relação entre imagem e vigilância.

No item 2.1 teremos uma análise que versa sobre a dimensão ideológica das prisões e seus subsequentes desdobramentos. Ressalto aqui a importância das chaves gramscianas para aplicar contraste e robustez teórica, nas quais nos apoiamos para avançar neste debate intrínseco a realidade neoliberal.

No item 3, com a discussão já encaminhada e contextualizada, possuímos as bases para adentrar a discussão central, que incide sobre a mercadorização de presos e as vicissitudes da forma presídio como tal.

No item 4 é chegada a hora de realizar uma análise em paralelo com a realidade norteamericana, tendo em vista o avanço excepcional do neoliberalismo e do Estado Penal como modus operandi. Temos como inescapável neste estudo o entendimento amplo dos movimentos do capitalismo cosmopolita, para tanto não advogamos em razão de um entendimento deslocado geograficamente de outras fontes que podem ser elucidativas para o estudo de nosso caso. Não raro, são feitas as devidas ressalvas às especificidades de cada realidade.

Finalmente, concluímos no item 5, que busca condensar com brevidade o que foi explicitado ao longo do estudo, com alguns apontamentos finais

\section{Forma Presídio: Dialética do Caos}

Hegel comenta que todos os grandes fatos e todos os grandes personagens da história mundial são encenados, por assim dizer, duas vezes. Ele se esqueceu de acrescentar: a primeira vez como tragédia, a segunda como farsa (MARX, 2011, p. 25).

Para realizar esta análise, será necessário regressar em tempos históricos para que seja possível avançar em termos teóricos. Ao contrário do que geralmente se pensa, o mercado por exemplo não surge antes das sociedades políticas, mas é surgido por estas; e, portanto, não pode ser visto como um fato social ${ }^{2}$ anterior às próprias sociedades, pois, na verdade este é derivado de um constructo social específico que se concretiza. As prisões, por sua vez, devem ser

${ }^{2}$ Por fato social, entende-se: "É fato social toda maneira de fazer, fixada ou não, suscetível de exercer sobre o indivíduo uma coerção exterior, (...) que é geral na extensão de uma sociedade dada, e, ao mesmo tempo, possui existência própria, independente de suas manifestações individuais” (DURKHEIM, 2007, p. 13). 
igualmente encaradas como fruto de uma ação política determinada em um específico momento histórico.

Diversos autores habituaram-se a apontar a formação do Estado de Providência (Welfare) após a chamada Grande Depressão de 1929, pelo menos nos países do Norte Global. No entanto, embora tenha se consolidado nesse período, as raízes de sua formação remontam o final do século XVIII e início do século XIX, quando milhares de trabalhadores foram obrigados a deixarem suas terras e assim constituíram uma massa de despossuídos - provendo apenas de sua força de trabalho - nos grandes centros urbanos. Por consequência, a celeridade desta mudança que alterou profundamente a estrutura social, atirou milhares de camponeses nas ruas, possuindo como moeda de troca apenas sua incólume força de trabalho ${ }^{3}$. Este acontecimento histórico foi o que Karl Polanyi chamou de a Grande Transformação, ou seja, o êxodo rural desordenado que superlotou os centros urbanos transformando para sempre as relações sociais.

Polanyi faz um balanço das movimentações históricas em direção ao capitalismo industrial, em sua época na Inglaterra do século XVIII. Para tanto aborda o movimento de enclosures ${ }^{4}$ iniciado em doses ainda moderadas no século XVI e que assume realmente sua envergadura no século da revolução industrial.

Ao analisar a história dos presídios, cabe lembrar que a prisão nasce com os Estados autoritários, onde Monarquias absolutistas empregavam no lugar das penas, castigos severos, suplícios e execuções para os desprivilegiados, criando em última instância uma atmosfera de medo como forma de controle da vida social.

Anteriores as prisões do século das luzes, era comum que as prisões abrigassem o que podemos chamar de resíduos sociais, ou seja, a união dos indesejados de todo tipo que "sujavam" as cidades europeias apenas com sua presença. Assim, as Houses of Correction 5 abrigavam aqueles enquadrados como vagabundos, ao mesmo tempo que higienizavam as metrópoles européias. Processo este que é semelhante ao que aconteceria anos mais tarde nos EUA, com a abolição da escravidão após a libertação dos negros norte-americanos $(1863)^{6}$.

\footnotetext{
${ }^{3}$ Em referência a venda da força de trabalho como condição de subsistência temos: "Esta relação social constitui a base do capitalismo - seres sociais que não dispõem de meios para subsistir - e é sempre reproduzida ampliadamente. Ela origina-se na expropriação massiva de terras camponesas a partir do século XV e nos "cercamentos parlamentares", realizados no século XVIII na Inglaterra, que extinguiam a propriedade camponesa através de decretos" (FONTES, 2017, p. 46).

${ }^{4}$ Como eram chamados os cercamentos na época.

${ }^{5}$ Inglaterra (1533).

${ }^{6}$ Retomaremos mais tarde esse ponto ao realizar um comparativo entre EUA e Brasil.
} 
Com a "superação" dos métodos medievais e das casas de correção, na esteira do processo de reformulação do sistema penal surgem as workhouses, instituições bastante peculiares do Capital Industrial que rapidamente ganharam notoriedade no continente europeu. Estas casas - como já sugere o nome - eram responsáveis por domesticar e treinar a força de trabalho excedente, que hiperconcentrada nos grandes centros urbanos da época ${ }^{7}$.

Logo, aqui temos dois movimentos concorrentes acontecendo: de um lado, o capitalismo industrial não consegue absorver a explosão de mão de obra trabalhadora nas indústrias, de outro, as circunstâncias produzem uma grande massa de camponeses desempregados a vagar pelas ruas.

É justamente nesse momento que as prisões aparecem como linha auxiliar da fábrica ao "absorver" essa massa - legitimada pelo aparato jurídico-institucional - para realizar trabalhos de manufatura, proporcionando assim um outro movimento no seio das relações de produção: a redução dos salários a valores miseráveis e a superexploração ${ }^{8}$ do trabalho pela grande demanda das fábricas.

\section{Ressocialização e a incompatibilidade de sua própria forma}

Só posso esperar que não esteja longe o tempo em que as forças, o pelourinho, o patíbulo, o chicote, a roda, serão considerados, história dos suplícios, como a marca da barbárie dos séculos e dos países e como as provas da fraca influência da razão e da religião sobre o corpo humano (RUSH, 1935, p.30 apud FOUCAULT, 2014, p. 15).

É somente após o Iluminismo que a concepção e reeducadora da pena ganha corpo teórico e espalha-se pela Europa. Cabe aqui destacar o livro Dos Delitos e das Penas, do italiano Cesar Beccaria ${ }^{9}$, que prepara o novo arcabouço jurídico-institucional do Estado Moderno. A privação de liberdade com o fim de restabelecer a buon ordini pela prevenção de crimes, é até hoje utilizada para a defesa do direito penal. Explicitado em:

\footnotetext{
7 Aqui, é imprescindível ressaltar o argumento de La grande transformation (Polanyi), no qual a hiperconcentração de trabalhadores nas cidades surge do movimento de enclosures, culminando na expulsão do trabalhador rural do campo desencadeando uma massa de despossuídos.

${ }^{8}$ Presente no trabalho de Ruy Mauro, o conceito de superexploração do trabalho consiste no dramático aumento de trabalho excedente como reapropriação da produção, acontecendo por duas vias: Ou pelo aumento da exploração pelo aumento da jornada diária de trabalho; ou pelo simples aumento da intensidade do trabalho. Também é possível que as duas vias aconteçam concomitantemente.

${ }^{9}$ Nascido em março de 1738, em Milão. Elabora a reforma do Sistema Penal e cabe ressaltar, foi também influenciado pela obra filosófica de Monstesquieu.
} 
Os princípios reabilitadores ou ressocializadores da pena tem como antecedente importante esses delineamentos de Beccaria, já que a humanização do Direito Penal e da pena é requisito indispensável. É paradoxal falar da ressocialização como objetivo da pena privativa se não houver o controle do poder punitivo e a constante tentativa de humanizar a justiça e a pena (BITTENCOURT, 2011, p.57).

Assim, é nesse vocábulo avulso que se cristaliza o discurso que legitima há mais de duzentos anos o encarceramento - como vimos, muitas vezes arbitrário - de pessoas historicamente marginalizadas e a subsequente manutenção da desigualdade. A ressocialização ${ }^{10}$ dos detentos aparece como resultado histórico em uma tentativa de humanizar os castigos, trazendo uma alternativa aos suplícios que aquela altura ${ }^{11}$, já econtravam-se devidamente rotulados pela opinião pública esclarecida como cruéis, excessivamente violentos ou sem sentido.

No entanto, o caráter demasiadamente questionável da eficácia da ressocialização ${ }^{12}$ nos faz duvidar de sua razoabilidade em termos práticos, pois enquanto na teoria sua capacidade mostra-se convincente, na prática sua eficácia é reticente. Para tanto, nesse ponto é preciso questionar-se: a ressocialização não funciona como cortina de fumaça à medida que retornamos para antes de sua formulação? Ou seja, de quando era necessário controlar a população pelo medo e os internos poderiam ser mortos ou torturados e suplicavam pela liberdade.

As penas privativas modernas são parte estruturante de um locus social que nos faz experienciar as sociedades mais desiguais, violentas, vigiadas e doentes de que se tem notícia. Não é novidade que as finalidades das penas são senão reproduzir a violência - tanto a de Estado quanto a incrustada socialmente - e formar verdadeiros depósitos humanos que não cessam de multiplicar-se. Em Zaffaroni, encontramos respaldo ao dizer que as penas funcionam como "inflição de dor sem sentido" além de não cumprir quaisquer de suas finalidades reais, e ainda complementa: "achamo-nos, em verdade, frente a um discurso que se desarma ao mais leve toque com a realidade" (ZAFFARONI, 2001, p. 12).

No entanto, em toda sua obra, Beccaria frisa a importância da forma preventiva da pena até mesmo grau superlativo quando comparada a função privativa de liberdade ${ }^{13}$ da mesma. Se tomamos por exemplo a realidade brasileira, observamos exatamente o oposto do que

10 A Ressocialização consiste na reintegração de alguma pessoa ao convívio social, por meio de políticas humanísticas, tornando sociável aquele que praticou condutas reprováveis pelas normas e sociedade (DIAS, 2009). 11 "Que as penas sejam moderadas e proporcionais aos delitos, que a de morte só seja imputada contra os culpados assassinos, sejam abolidos suplícios que revoltam a humanidade" (SELLIGMAN, 1901 apud FOUCAULT, 2014). ${ }^{12}$ Chamo atenção para esse termo pois é justamente a união de "eficácia" e (capacidade de ) "ressocialização" que galvaniza as bases para as privatizações de hoje.

13 "Todo legislador sábio deve antes procurar impedir o mal do que repará-lo" (BECCARIA, 2007, p.101). 
preconizava o autor italiano do século de XVIII que institucionalizou o conceito de ressocialização. Com penas que ultrapassam os 30 anos, o Brasil possui a $4^{\mathrm{a}}$ maior população carcerária do mundo, com 726 mil presos ${ }^{14}$ e um aumento de $800 \%$ nos últimos 20 anos. Diferentemente do que enfatiza Beccaria, a primazia do Direito penal brasileiro está em punir, excluir e segregar, e nada previne à medida que socializa a barbárie.

A distância entre o "ser" e o "dever ser" é tamanha que não é preciso ir longe das próprias matrizes do Direito Penal para entender a vulnerabilidade deste sistema. $\mathrm{O}$ olhar atento percebe a contradição em sua própria forma, descolada da realidade criada por si mesmo, o direito ficcional ${ }^{15}$ aprisiona a realidade em sua totalidade aparente à medida que manipula a realidade concreta. Por consequência, são as múltiplas totalidades aparentes ${ }^{16}$ que irão permitir a contingência na forma das leis e o seu descolamento da realidade, as quais seguem interesses econômicos e atuam como guardiãs do direito privado. Desta forma: “[...] o direito assume sua forma específica de abstração e generalidade, de aplicabilidade e validade universal, sem levar em consideração as pessoas concretas" (PACHUKANIS, 2017).

Portanto, para além das outras deformações do direito, o princípio ressocializador apresenta-se como obsoleto, legitima a violência dentro e fora dos muros ${ }^{17}$ e cada vez mais seletivo. Via de regra, o sistema legitimado por esse princípio tem como ferramenta o controle por choque para os miseráveis das cidades ${ }^{18} \mathrm{e}$ as classes menos favorecidas, fazendo com que a prisão reproduza a desigualdade à medida que fomenta uma massa de irrecuperáveis $^{19}$.

Fato é que o sistema penal, apoiado no mito ${ }^{20}$ da ressocialização e na razão neoliberal, não tem por objetivo encerrar a criminalidade, mas sim sistematizar essa criminalidade de modo que a pobreza seletiva continue promovendo a competição generalizada, gerar um custo cada vez menor para o Estado e cada vez maior para a população e irradiar o controle pelo medo de agir coletivamente. Dessa forma, não há horizonte favorável que não passe pela ruptura com esse sistema e com suas formas.

${ }^{14}$ Ver grafico I no anexo

${ }^{15}$ Atento aqui para a ficcionalidade do direito. Esta reside no fracionamento da norma (civil, penal, trabalhista...) que impossibilita o entendimento da realidade, pois está não pode ser equacionada.

${ }^{16} \mathrm{O}$ que chamo de múltiplas totalidades aparentes é a tentativa de fomentar a unidade quando sua forma está dada como difusa e fracionada.

${ }^{17}$ Quanto a violência: "nunca saiu de cena, sobretudo, contra os corpos negros e pobres das periferias brasileiras" (ANDRADE, 2012).

${ }^{18}$ Aqui podemos fazer um paralelo com os despossuídos - supracitados - que se acumulavam nas cidades após os cercamentos.

${ }^{19}$ Argumento comumente utilizado pelos abolicionistas penais.

${ }^{20}$ Segundo Andrade: "[...] um mito que nunca mais sai de cena: está fundada uma das maiores e mais resistentes mitologias do mundo ocidental" (ANDRADE, 2012, p. 309). 


\section{A Espetacularização do Cárcere e o Império da imagem}

Em janeiro de 2017 todo o Brasil parou para assistir a um drama específico de nosso tempo: a realidade brutal do sistema carcerário brasileiro. A rebelião iniciada em $1^{\circ}$ de janeiro no complexo prisional Anísio Jobim (RN) deixou 56 mortos em uma das rebeliões mais sangrentas registradas, além de um grande ponto de interrogação sobre a capacidade e eficácia de um sistema prisional que parece incitar a violência humana.

Em teoria, a função da medida privativa de liberdade prescreve o objetivo concreto de ressocialização de indivíduos denominados “desviantes".

Qualificado em Guy Débord ${ }^{21}$ como "uma relação social entre pessoas mediada por imagens", o Espetáculo difundindo da lógica vigiar e punir ${ }^{22}$, encontrou seu ápice recente na convulsão de janeiro de 2017. As imagens das rebeliões, massivamente divulgadas na mídia hegemônica, colaboram para a formação de um imaginário de medo e desconfiança que em última instância atua em vias de estabelecer uma guerra psicológica no âmbito da sociedade civil.

O efeito mais impressionante acontece no nível especular - ou seja, do telespectador que recebe o espetáculo e encontra-se preso na condição de anestesia ${ }^{23}$ gerada, fadado a repetir a ação - foi a difusão viral da venda de Dvd's com as cenas de câmeras de segurança dos presídios. ${ }^{24}$ Entre decapitações e cenas brutais que nos relembram a época de suplícios ou ainda os castigos sofridos por prisioneiros na época medieval, a população média deleita-se com gozo de ver outra pessoa sendo punida ou morta.

Se buscamos compreender a formação da subjetividade desse sujeito que diverte-se com o trágico, mas paralisa-se ao fazê-lo, é necessário investigá-lo sem perder de vista a racionalidade neoliberal que se apresenta como espetáculo. Para tanto, a racionalidade neoliberal - por mais que possua a face hegemônica - não deve ser vista puramente como uma causa externa aos indivíduos, pois é justamente a relação total que impõe a racionalidade ao sujeito, que, ao introjetá-la, altera sua relação real com o mundo que o circunda. A competição como regra de conduta afasta o sujeito de outros sujeitos à medida que o conecta com o mundo

${ }^{21}$ Débord, La Société du Spetacle. 1967.

${ }^{22}$ Em referência à célebre obra de Michel Foucault sobre os presídios. O termo alude a tanto aos castigos sobre os corpos que "evoluem" desde o suplício até a suavização das penas privativas de liberdade, quanto a vigilância social que viria a reger o controle das massas.

23 "O espetáculo não deseja chegar a nada que não ele mesmo" (DÉBORD, 1997).

24 Disponível em: http://www1.folha.uol.com.br/cotidiano/2017/01/1850612-dvds-com-imagens-de-massacreem-prisao-do-am-se-esgotam-em-camelos.shtml 
em abstrato. Portanto, ressalto a importância da dispersão endêmica da racionalidade neoliberal, de um tal modo que fomos capazes inclusive de naturalizá-la (DARDOT; LAVAL, 2011).

A era da imagem permite uma interação incrível entre as políticas governamentais repressivas, emendas constitucionais ${ }^{25}$, discursos de militarização urbana e programas de TV e rádio que acompanham policiais em perseguições além de telejornais que reforçam, com cenas de violência, o clima de insegurança pública apontando como solução aumentar a repressão. Infelizmente, tal simbiose de eventos vem encontrando eco na sociedade e cada vez torna-se mais comum o apoio a discursos repressivos, proto-fascistas e autoritários devido ao consenso que circunda a esfera política e civil quanto à segurança pública.

No entanto, é nosso trabalho dizer que para que fosse possível alcançar esse patamar empresarial de subjetividade ${ }^{26}$, foi porque de outro lado foi desmantelado o espírito da razão pública, e, deste modo, é exatamente a antipolítica da solidariedade social o ponto de inflexão desse sujeito que se esgota em si.

\section{Aparelho, Repressão e Ideologia}

Cabe ainda ressaltar as fissuras por trás dos acontecimentos supracitados. O presídio Anísio Jobim (RN), à época do massacre, era administrado desde 2011 por um grupo de empresas criado por Luiz Gastão Bittencourt da Silva, atual presidente da Federação do Comércio do Ceará (Fecomercio). A concessão à iniciativa privada se dá sob os argumentos de "peso aos cofres públicos", ineficiência estatal e caos na gestão pública dos presídios brasileiros. A título de comparação, um preso no sistema público custa entre 1.400 a 2.400 reais, razão pela qual argumenta-se que seria inviável a manutenção dos gastos que ultrapassam 20 bilhões anualmente, com todo o sistema carcerário. Entrementes, a Umanizzare ${ }^{27}$ é responsável pela gestão do Compaj e de outros seis presídios no Amazonas. Conforme o relatório do MP, a empresa cobra $\mathrm{R} \$$ 4,7 mil reais para cuidar de um detento do Anísio Jobim - praticamente o dobro do que um preso custa em média no restante do país. ${ }^{28}$

\footnotetext{
${ }^{25}$ Como por exemplo a Proposta de Emenda Constitucional 33/2012 de redução da maioridade penal.

${ }^{26}$ O Homem Empresa, em referência a Dardot e Laval

27 Uma das empresas do grupo responsável pela administração do presídio desde 2014, substituindo a "Auxílio" por ações judiciais trabalhistas.

${ }^{28}$ Ver matéria: https://g1.globo.com/politica/noticia/criada-pelo-mesmo-dono-empresa-que-antecedeu-aumanizzare-no-compaj-foi-inabilitada-para-licitacao.ghtml.
} 
Não é à toa que o Estado do Amazonas possua o sistema carcerário mais caro do Brasil $^{29}$. A realidade recente é que o depreciado sistema carcerário tornou-se um nicho de mercado para a iniciativa privada. Consequência das terceirizações que vem acontecendo no setor público, a diferença das concessões e privatizações é que estas já estão regulamentadas por Lei das PPP's que permite contratos de até 30 anos entre o Estado e entes privados ${ }^{30}$. A título de exemplificação, apenas entre 2013 e 2016 a Empresa Umanizzare recebeu R\$ 809.000.000,00 milhões de reais apenas com a administração de presídios anteriormente públicos.

Para compreender melhor a lógica da privatização dos presídios, seus objetivos e desdobramentos, é preciso olhar além daquilo que se vê, do que está posto e é visível aos primeiros sentimentos humanos, para que seja possível enxergar a realidade. Os estudos relativos aos presídios são vastos, e o aparecimento dessa instituição é frequente nos variados ramos analiticos.

Em seu célebre Aparelhos Ideológicos de Estado, Althusser apresenta a necessidade em distinguir os Aparelhos de Estado (AE’s) dos chamados Aparelhos Ideológicos de Estado (AIE's) ${ }^{31}$. Em sua diferenciação conceitual, estabelece que os aparelhos (repressivos) de Estado não se confundem com os Aparelhos Ideológicos de Estados, pois "podemos constatar que enquanto o aparelho (repressivo) de Estado, unificado, pertence inteiramente ao domínio público, a maioria dos Aparelhos Ideológicos de Estado (na sua dispersão aparente) advém pelo contrário do domínio privado" (ALTHUSSER, 1985).

Tendo em observância o caráter burguês do qual derivam as noções de público e privado (ALTHUSSER, 1985, p. 45), é necessário contudo analisar o estado de confusão intermitente e aparente entre esses conceitos. Em verdade, torna-se cada vez mais difícil separar aquilo que é público, daquilo que é privado, sobretudo pela absorção generalizada da lógica mercantil, em aderência à racionalidade neoliberal totalizante, tanto das políticas governamentais quanto dos sujeitos. Argumentado em:

De fato, um dos efeitos da nova gestão pública, é que os limites entre o setor público e o setor privado se embaralham. Aliás, a própria ideia de um setor público cujos princípios transgridem a lógica mercantil é posta em questão

${ }^{29}$ Ver matéria: http://g1.globo.com/bom-dia-brasil/noticia/2017/01/custo-de-preso-no-amazonas-e-o-dobro-damedia-nacional.html

${ }^{30}$ Lei 11.079, de 30 de Dezembro de 2004

${ }^{31}$ Para um entendimento reto dos referidos Aparelhos temos como de Estado: o Governo, a Administração, o Exército, a Polícia, os Tribunais, as Prisões, etc., que constituem aquilo a que chamaremos a partir de agora o Aparelho Repressivo de Estado; Enquanto por Aparelhos Ideológicos de Estado temos: o Religioso, Escolar, familiar, jurídico, político, sindical, midiático e cultural com suas respectivas especificidades (ALTHUSSER, 1985, p.67). 
com a multiplicação das relações contratuais e delegações, bem como as transformações sofridas pelo emprego público no sentido de uma maior diversidade de formas e de uma precariedade mais desenvolvida (DARDOT; LAVAL, 2011).

É incontornável preencher a lacuna deixada pelo enquadramento dos presídios como puramente repressivos. De antemão, deixo claro que não fazemos vista grossa para o caráter repressivo, extensivo e ostensivo que a forma presídio pode adquirir, mas em vista da realidade dramática das condições concretas e da capacidade de "reinvenção" do capitalismo neoliberal, a predominância deverá ser dada ao campo ideológico-político.

Antonio Gramsci, em dado momento de sua vasta obra, lança mão do conceito de Aparelhos Privados de Hegemonia, que aqui nos parece um elemento chave para o tema. Compreende-se por aparelhos privados de hegemonia: "organismos sociais coletivos voluntários e relativamente autônomos em face da sociedade políticos" (COUTINHO, 1999). Vale ressaltar que a abordagem gramsciana nos transmite uma percepção ampliada da realidade, na qual raramente seus conceitos são limitados e fechados, o que não quer dizer que estes não sejam contundentes.

Os aparelhos privados de hegemonia são parte atuante da sociedade civil ${ }^{32}$, e "representam a sociedade em suas diferentes, e até mesmo antagônicas, concepções de mundo, e possuem uma relativa autonomia em relação à sociedade política" (MOTTA, 2012). Ademais, esses aparelhos articulam-se de modo a construir o consenso, (des)politizar as ações coletivas e de fomentar uma consciência política ampla.

Das escolas, passando pelos presídios, tribunais e igrejas, os aparelhos privados de hegemonia de Gramsci divulgam as ideologias - dominantes - de uma determinada perspectiva de mundo, e, consequentemente, agem de modo a elaborar e manter consensos sociais. Assim, Gramsci é enfático:

\begin{abstract}
A escola como função educativa positiva e os tribunais como função educativa repressiva e negativa são as atividades estatais mais importantes neste sentido: mas, na realidade, para este fim tem um multiplicidade de outras iniciativas chamadas privadas que formam o aparelho da hegemonia política e cultural das classes dominantes (GRAMSCI, 2000, p. 284 apud MOTTA, 2012, p.115).
\end{abstract}

Por mais que as dicotomias entre público e privado, Estatal/Empresarial sejam oriundas do direito burguês, sua dinâmica de predominância e alternância podem nos dar fortes indícios

${ }^{32}$ Fundamental conceito gramsciano, a sociedade civil pode ser encarada como o conjunto dos aparelhos privados de hegemonia. "Sua força reside menos na coerção que no fato de que suas grades são tanto mais eficazes quanto menos visíveis se tornam" (COUTINHO, 1989). 
da realidade das relações de hegemonia dentro do Estado ou sociedade civil e a medir os avanços dos aparelhos privados de hegemonia em conquistar o consenso. Nessa esteira, a Lei das PPPs que abre caminho para ainda inconstitucional ${ }^{33}$ entrega de presídios para a iniciativa privada criar valor, e, consequentemente, lucro com pessoas em situação de cárcere não demonstra nada menos que uma modificação profunda, e de novo tipo ${ }^{34}$, para os aparelhos privados de hegemonia gramscianos. Nos defrontamos, agora, com uma nova forma presídio: o Presidio-Empresa.

\section{O Caráter Fetichista da Forma-Presídio Ribeirão das Neves}

Modelo inédito na América latina, o Presídio de Ribeirão das Neves inaugurado em janeiro de 2013, cristaliza aquele que pode se tornar um novo projeto de acumulação capitalista no seio do sistema prisional da Latino Americano. Ao incorporarmos conscientemente que o projeto privado só é capaz de assumir sua forma concreta quando o público recebe o rótulo de ineficiente ou inviável economicamente, lançamos luz para a criação de um nicho de mercado: os Complexos Industriais Penais.

Já não fossem suficientes as contradições presentes no ideário da forma presídio - por exemplo, a manutenção do mito ressocializador da pena incorporado (e intocado) no século XIX e o preenchimento previsto em contrato, de lotação de $90 \%$ do presídio como piso -, observamos a alvorada de uma contradição ainda mais sistêmica e que pode expor as vísceras do capitalismo.

O ponto de inflexão no momento trata-se da mercadorização dos detentos, que assumem a forma abstrata de mercadoria e consequentemente lhes são conferidos valor de troca ao passo que consolida-se um mercado restrito onde esses presos serão trocados seguindo um fator exclusivo, que aparece na forma de pergunta: "o quanto este preso pode trazer risco para o presídio?" Teórico dessa “forma” que adquire a mercadoria, Marx elucidou:

Uma mercadoria aparenta ser, à primeira vista, uma coisa óbvia, trivial. (...) Mas tão logo aparece como mercadoria, ela se transforma numa coisa sensível-suprassensível (MARX, 2012, p.146).

33 Além de contar com fundos especiais inconstitucionais temos: Lei 11.079/2004. Art. $4^{\circ} \mathrm{Na}$ contratação de parceria público privada serão observadas as seguintes diretrizes: III - indelegabilidade das funções de regulação, jurisdicional, do exercício do poder de polícia e de outras atividades exclusivas do Estado. Assim, ressalta-se a incompatibilidade da própria lei, que veda concessões que antes eram exclusivas do Estado, com a privatização dos presídios.

${ }^{34}$ Gramsci tem o hábito de separar os aparelhos privados de hegemonia entre tradicionais e de novo tipo. 
Para depois acrescentar:

O caráter misterioso da forma mercadoria consiste, portanto, simplesmente no fato de que ela reflete aos homens os caracteres objetivos dos próprios produtos do trabalho, como propriedades sociais que são naturais a essas coisas e por isso, reflete, também a relação social dos produtores com o trabalho total como uma relação social entre os objetos, existente à margem dos produtores (MARX, 2012, p.147).

Ao transformar seres humanos em mercadorias, realiza-se então a avaliação de seus antecedentes penais e se existe algum tipo de vínculo entre o indivíduo e facções criminosas. $\mathrm{O}$ que poderíamos chamar de "higienização" de um presídio é, o que em última instância, pode determinar a sobrevivência de um projeto em expansão ${ }^{35}$.

Se, por um momento, começamos a atentar para os índices relativos aos detentos de Ribeirão das Neves, observaremos que sua população carcerária é formada em sua maioria por jovens e com longas penas. Penas das quais não se prescrevem crimes violentos ou de grave ameaça a pessoa. Portanto, ao caráter imagético do presídio mantém-se preservado não abalar a reputação deste, que é um dos mais recentes projetos do neoliberalismo.

De certo, a Lei 11.079/2004, chamada de Lei das PPP's, abre as veredas para as concessões, terceirizações e privatizações no setor público e no nosso caso nos presídios. No entanto, a abrangência de sua letra permitiu muitas interpretações, principalmente quanto à aplicabilidade da lei no sistema carcerário. Portanto, para não deixar dúvidas aparentes, surgiu o Projeto de Lei $n^{\circ}$ 513/11 que estabelece as diretrizes da Parceria Público-Privada para construção e administração de estabelecimentos penais. Na letra deste projeto, temos: "[...] a iniciativa privada precisa estar livre para explorar a mão-de-obra do preso como bem quiser" e aponta como justificativa primeira de seu projeto a eficiência da ressocialização que o sistema atual "não possibilita"36.

Seria de grande ingenuidade pensar que não existe um forte jogo de influências para a montagem do que é possível chamar de o "quadro disciplinar" ou o "mercado fantasma de presos" $"$. A procura por presos mais dóceis e fáceis de lidar andam pari passu a: (1) Remuneração Mensal vinda do Estado; (2) Manutenção da Própria "forma" Empresa do presídio; (3) "Venda" positiva da imagem do projeto.

${ }^{35}$ Ver no Anexo I os gráficos II, III, IV e V.

${ }^{36}$ Disponível em: http://www25.senado.leg.br

${ }^{37}$ Aqui utilizo o termo fantasma tanto para chamar atenção a realidade obscura, silenciosa, na qual se desenvolve mercado de presos, quanto para aludir Karl Marx quando este mencionara a forma fantasmagórica que esta pode assumir no Livro I do Capital. 
Para um projeto de Presídio-Empresa que aparece messianicamente para salvar o Sistema Penitenciário Brasileiro, sucateado e jogado as traças pela "ineficiência do Estado", consolidado na retórica reacionário burguesa de que "vagabundo tem mais é que apodrecer lá dentro" e "bandido bom é bandido morto", seriam inadmissíveis motins e quebra-quebras pelo menos até o terreno político do consenso estar assegurado.

Deste modo, o que ocorre é que a forma Presídio-Empresa (privado) quer se assemelhar ao presídio estatal (público), propagando a farsa de que atua sob as mesmas condições e adquire melhores resultados (eficiência) para convencer a sociedade civil, e, em última análise, expandir seu projeto. Não obstante, esta roupagem que os presídios-empresa toma emprestada, é nada mais que uma inversão da realidade concreta dos presídios públicos brasileiros.

Tendo em vista não somente as condições atípicas de seu funcionamento, as cadeias públicas não contam com a possibilidade de escolher se seus presos serão de facções ou se possuem penas gravíssimas $^{38}$; de ter um fundo especial que pode ser usado pela contratada para realizar reformas e investir nos recursos humanos do presídio. Assim, concluo que as comparações realizadas quanto a eficiência, segurança e capacidade dos dois tipos de presídio são inverossímeis e não encontram apoio na realidade.

No que diz respeito à capacidade ressocializadora, tanto o presídio público quanto o privado se mostram ineficazes. Nesse ponto, porém, a diferença reside na forma presídioempresa mover-se para e pelo lucro, visto que se as celas estiverem vazias, este não gera lucro, e consequentemente, desmorona. Se, não nos posicionarmos contra este projeto, não existirá horizonte próximo para resolvermos a superlotação de presídios e a violência urbana.

\section{O Sistema Carcerário Norte-Americano: Produto de Exportação}

Os Estados Unidos contam com 2,2 milhões de pessoas em regime fechado ${ }^{39}$ - dos quais 1 milhão são negros -, o equivalente a $25 \%$ de toda a população carcerária existente. Em menos de 40 anos, a população carcerária deu um salto de $500 \%$ e há algum tempo é a maior do mundo.

Contudo, por trás da realidade acima há todo um arcabouço histórico que nos impossibilita de compreender o presente em sua totalidade sem que seja feita a devida contextualização. Curiosamente, na era da informação não são raras as vezes que nos

${ }^{38}$ Termo jurídico para caracterizar penas graves.

${ }^{39}$ Somadas as Penitenciárias de tipo municipal, estadual ou federal e se pública ou privada. 
defrontamos com argumentos infundados e com mais juízo de valor do que ideias amplas e embasadas.

Quando isso acontece, caímos na falácia do presentismo ${ }^{40}$, ou seja, analisamos apenas a história recente sem atentar para o macro, o que a "grande história" pode nos fornecer e até mesmo mudar o que antes considerávamos verdadeiro. Para tanto, far-se-á sempre que possível o esforço de contextualizar dialeticamente os acontecimentos, tendo por objetivo mostrar o grande quadro e não apenas um pedaço dele, pois assim, mutila-se a realidade dos fatos.

No que tange o grande tema das prisões, nos EUA comecemos pela abolição formal do regime escravocrata (1863) e a 13 emenda $^{41}$. Quando desmorona um regime que tinha por base a força de trabalho escrava, é antes de mais nada necessário entender que existem forças inconciliáveis no tecido social que lutam entre si, com interesses igualmente distintos. No caso, enquanto uma porção do país se industrializava e com isso, aumentavam os anseios por um mercado consumidor amplo e "livre" para consumir (Norte), a outra porção (Sul) majoritariamente rural apoiava-se na mão de obra-escrava para sustentar a economia.

Assim, nos Estado Unidos, como em grande medida dos processos de libertação pelas Américas, não foi a benevolência ou remorso das elites (ou da metrópole) que permitiu a libertação dos negros escravizados. Mas justamente a necessidade do capital de uma colônia já independente, de reciclar-se, no caso, expandindo a mão de obra assalariada voltada para consumo que mais tarde culminaria na vitória da porção industrializada, significando o fim da escravidão.

Contudo, a 13 emenda que legitimou juridicamente a liberdade da população escravizada, ao mesmo tempo deu margem para que os negros recém libertos retornassem à condição de compulsoriedade laboral, mas agora legalmente livres pelo sistema (ver nota de rodapé). O que ocorre em consequência é a criminalização desse segmento, pois é justamente enquadramento no código penal que permitirá o retorno (ou repetição) ao trabalho compulsório. A diferença é que agora o trabalho escravizado acontece em um novo ambiente disciplinar: o Presídio.

Com diferenças pontuais, a maioria dos negros nesta nova condição de dominação era enquadrada penalmente por crimes como vadiagem e às vezes simplesmente por não ter trabalho. Podemos dizer que a reinserção do negro na sociedade foi dada pelo presídio, como

${ }^{40}$ Consiste em analisar, erroneamente, o fato ou assunto como se estivesse em uma bolha histórica, de maneira descolada, como se não houvessem antecedentes e prosseguimentos

${ }^{41}$ Emenda à constituição norte-americana: "Não haverá, nos Estados Unidos ou em qualquer lugar sujeito a sua jurisdição, nem escravidão, nem trabalhos forçados, salvo como punição de um crime pelo qual o réu tenha sido devidamente condenado." 
projeto que evidencia a crueldade de um sistema que engendra a exclusão e a miséria. Por isso, insisto no aspecto formal da abolição da escravatura nos EUA, que por mais que amparado juridicamente deixava brechas para que materialmente a escravidão se reproduzisse e se firmasse em uma grande farsa de igualdade que segregou - e ainda segrega - mais do que emancipou os escravos da sua antiga forma de dominados.

O que anuncia-se como boom do encarceramento nos EUA, é fruto de um consenso entre políticas neoliberais austericidas e o aumento generalizado do poder de polícia estatal (ou a repressão de Estado legitimada pelo aparato jurídico e a discricionariedade de presidentes superpoderosos). Fato é que que a partir de 1975 observa-se uma clara mudança de paradigma marcada pela supressão do Estado-Providência de décadas anteriores, para um austero Estado Penal defensor da lei e da ordem.

No entanto a retração do Estado-Providência gera por sua vez o aumento da pobreza e do desemprego, fazendo paralelamente com que os atingidos caíssem na informalidade e no tráfico de drogas. Naquele momento, ganha corpo a retórica da segurança pública - tão presente nos discursos de Nixon e Reagan - que se tornaria o grande locus político de quem quisesse receber votos. Deste modo, as cruzadas contra a criminalidade são legitimadas tanto pela forma jurídica quanto por uma opinião pública confusa e desorganizada, quando na verdade o que se coloca é a "guerra contra a pobreza" para conter possíveis tumultos causados por um ambiente de insegurança generalizada (WACQUANT, 2007).

A começar pelo Tennesse, os presídios privados espalham-se pelo país fomentando uma miríade de parcerias entre governos estaduais e consórcios empresariais descentralizados ${ }^{42}$, terceirizações inescrupulosas e enriquecimento ilícito. Isso tudo em grande medida sustentado pela retórica de diversificar e aliviar o orçamento estatal. Para este argumento, Wacquant é sensível ao afirmar: "o aumento dos orçamentos e do pessoal destinados ao sistema carcerário só foi possível ao se amputarem as somas que seriam destinadas às ajudas sociais, à saúde e à educação" (WACQUANT, 2007, p. 96).

Não obstante, denota-se a formação de um nicho econômico que é fruto não apenas do capitalismo neoliberal descontrolado, mas da hiperinflação da população carcerária que precisará de presídios novos para ser administrada. Enquanto o Governo teria de criar uma penitenciária para mil presos a cada cinco (05) dias, o que seria absolutamente inconcebível, a iniciativa privada entrega em 18 meses um complexo penitenciário de ponta (WACQUANT, 2011, p. 97).

${ }^{42}$ Seguindo o modus operandi de Holdings. 
Sem perder de vista a privatização dos presídios, atento para a formação ou reforço da economia que circunda a hiperinflação de presos no sistema carcerário, composta por empresas alimentícias, de transporte, montadoras, telefonia, segurança privada, escritórios de advocacia sem mencionar as empresas relacionadas a construção civil. Apenas para se ter uma ideia, entre 1985 e 1995, os detentos sob custódia de empresas privadas saltou de 1.345 para 50 mil, revelando o projeto de privatização total nas fronteiras norte americanas (WACQUANT, 2011). Para condensar aquilo que procura-se evidenciar, retomamos o pensamento em:

Um filósofo produz idéias, um poeta versos, um pastor sermões, um professor manuais etc. Um criminoso produz crimes. Se considerarmos um pouco mais de perto a relação que existe entre este ramo da produção e o conjunto da sociedade, revelaremos muitos preconceitos. O criminoso não produz apenas crimes, mas ainda o Direito Penal, o professor que dá cursos sobre Direito Penal e até o inevitável manual onde esse professor condensa o seu ensinamento sobre a verdade (MARX apud LEFEBVRE, 1968, p. 79- 80).

E depois acrescenta:

O criminoso produz uma impressão, que pode ser moral ou trágica; desta forma ele auxilia o movimento dos sentimentos morais e estéticos do público. Além dos manuais de Direito Penal, do Código Penal e dos legisladores, ele produz arte, literatura, romances e mesmo tragédias. O criminoso traz uma diversão à monotonia da vida burguesa; defende-a do marasmo e faz nascer essa tensão inquieta, essa mobilidade do espírito sem a qual o estímulo da concorrência acabaria por embotar. O criminoso dá, pois, novo impulso às forças produtivas [...] (MARX apud LEFEBVRE, 1968, p. 79-80).

No entanto, este atrasado projeto prisional toma forma de modelo para a América Latina, criando os arquipélagos de encarceramento (GRAHAM, 2016, p. 176) nos quais certas geografias são "privilegiadas" para fazer parte das estatísticas prisionais. Da mesma forma como acontecia nas Houses of Correction, os complexos penitenciários se proliferam à medida que removem segmentos indesejados da sociedade.

Historicamente marginalizados, periféricos e negros são estruturalmente atenazados pelo sistema penal, à revelia dos crentes na mão punitiva do Estado Penal, a prisão "funciona cada vez mais como uma alternativa ao emprego; uma forma de eliminar, ou neutralizar, uma parcela considerável da população que não é necessária como produtora" (GRAHAM, 2016, p. 177).

A política de hiperencarceramento nos EUA além de neutralizar grupos estigmatizados - com medo de seu comportamento imprevisível - pode ser vista como uma guerra racializada e periferializada interna, travada entre o Estado e os pobres das cidades. Neste ínterim, a sociedade vive marcadamente uma democracia penal. 
Quando relacionamos o modelo estadunidense com o brasileiro, no que tange à política de encarceramento, podemos ser demasiado simplistas e perder de vista o processo histórico de cada nação. Para tanto, é necessário respeitar as especificidades de cada caso e analisar o contexto em questão.

Se resgatarmos a relação histórica entre Estados Unidos e Brasil, temos marcadamente uma relação de dependência costurada ao longo dos anos, na qual importamos não apenas tecnologias como os mais variados receituários jurídico-institucionais. Encontramos sustento naquilo que se convencionou o bumerangue de foucault ${ }^{43}$ que versa sobre a exportação cultural que reforça os sistemas de poder mundial, colaborando para um sistema mundial de encarceramento ostensivo e extensivo como télos de conduta. Thomas Heiner atenta para o fato de que o "arquipélago" dos complexos industriais penais funciona tanto quanto matriz quanto como circuito, e ao mesmo tempo "em um ciclo de retroalimentação que circula entre os “espaços negros" coloniais estado-unidenses nacionais e estrangeiros" (HEINER, 2007, p. 84).

\section{Considerações finais}

O presente estudo teve por intuito denunciar a realidade atroz dos presídios brasileiros, almejando contribuir para o debate atemporal que diz respeito ao cárcere, às penas e aos castigos. Além, é claro, de incidir sobre temáticas pouco exploradas que transcendem a frieza da letra do direito ou do cálculo econômico, em busca de um entendimento mais amplo que pudesse explicar com rigor, tal miséria de nosso tempo.

Os conceitos de ressocialização e mercadorização de presos foram as duas artérias de análise que balizaram este trabalho. De todo modo, os conceitos gramscianos - em especial os aparelhos privados de hegemonia - representam importantes chaves analíticas para a discussão da nova lógica carcerária no sistema neoliberal, assim como o conceito de espetáculo e mercadoria.

Atualmente, não podemos separar os presídios brasileiros do contexto sistêmico no qual estão inseridos. Em tempos de avanço do neoliberalismo como razão prática, cortes em direitos 
e investimentos sociais e campanhas políticas que convergem ao austericídio aceitamos a lógica da concorrência como conduta hegemônica.

Aguçado pela desertificação dos serviços públicos, o artifício da privatização é dado como solução simples dos nossos problemas. Na esteira do receituário neoliberal, importamos - como de costume - o que melhor exemplifica a confusão mencionada neste estudo: as Parcerias Público Privadas (PPP's). Derivado de uma desacolhedora ideologia punitiva, que sequer contém o aumento dos crimes e gentrifica o caos, eis que ressurge o ideal da privatização para solucionar a gravidade de um drama social ${ }^{44}$. Por fim, os presídios privados são tão incompatíveis com o projeto de ressocialização quanto o próprio capitalismo é incompatível com a democracia social.

\section{REFERÊNCIAS}

ADAUMIR, José. A privatização dos presídios: uma ressocialização perversa. Rio de Janeiro. Ed. Revan, 2016.

ANDRADE, Vera Regina. Pelas mãos da criminologia. Rio de Janeiro Ed. Revan, 2012.

BITENCOURT, Cezar Roberto. Falência da Pena de Prisão: causas e alternativas. São Paulo. Ed. Saraiva, 2011.

BRASIL. Senado Federal. Projeto de Lei $\mathbf{n}^{\mathbf{0}}$ 513/11. Disponível em: https://www25.senado.leg.br/. Acesso em: 16 maio 2019.

BRASIL. Lei 11.079/2004. Disponível em: https://www25.senado.leg.br/. Acesso em: 16 maio 2019.

COUTINHO, Carlos Nelson. A democracia como valor universal e outros ensaios. Rio de Janeiro. 1989.

COUTINHO, Carlos Nelson. Gramsci: um estudo sobre seu pensamento político. Rio de Janeiro: Civilização Brasileira, 1999.

DARDOT, Pierre; LAVAL, Christian. A nova razão do mundo: ensaio sobre a sociedade neoliberal. São Paulo: Boitempo, 2016.

DEBORD, Guy. A sociedade do espetáculo. Rio de Janeiro: Contraponto, 1997.

DURKHEIM, Émile. As Regras do Método Sociológico. São Paulo, Martins Fontes, 2007.

44 "No contexto de uma campanha de privatização a todo vapor lançada pelo governo Reagan e encorajada conjuntamente pelo thinks-thanks neoconservadores e pelas grandes firmas que operam em Wall-Street [...]" (WACQUANT, 2011, p. 285-286). 
FONTES, Virgínia. Capitalismo em tempos de uberização: do emprego ao trabalho. Marx e o Marxismo v.5, n.8, jan/jun 2017.

FOLHA. DVDs com imagens de massacre em prisão do AM se esgotam em camelôs. Manaus, 2017. Disponível em: http://www1.folha.uol.com.br/cotidiano/2017/01/1850612dvds-com-imagens-de-massacre-em-prisao-do-am-se-esgotam-em-camelos.shtml. Acesso em: 16 maio 2019.

FOUCAULT, Michel. Vigiar e punir. Ed. Vozes. Rio de Janeiro, 2014.

GLOBO. Criada pelo dono empresa que antecedeu a Umanizzare no Compaj foi inabilitada para licitação. São Paulo, 2017. Disponível em: https://g1.globo.com/politica/noticia/criada-pelo-mesmo-dono-empresa-que-antecedeu-aumanizzare-no-compaj-foi-inabilitada-para-licitacao.ghtml. Acesso em: 16 maio 2019.

GLOBO. Custo de preso no Amazonas é o dobro da média nacional. 2017. Disponível em: http://g1.globo.com/bom-dia-brasil/noticia/2017/01/custo-de-preso-no-amazonas-e-o-dobroda-media-nacional.html. Acesso em: 16 maio 2019.

GRAHAM, Stephen. Cidades Sitiadas. São Paulo: Boitempo. 2016.

GRAMSCI, Antonio. Cadernos do cárcere, v. III. Rio de Janeiro: Civilização Brasileira, 2000 .

LEFEBVRE, Henri. Sociologia de Marx. Rio de Janeiro: Forense, 1968.

MARINI, Ruy Mauro. Dialética da Dependência. 1973.

MARX, Karl. O 18 de Brumário de Luís Bonaparte. São Paulo, Boitempo, 2011.

MARX, Karl. O Capital I. São Paulo, Boitempo, 2011.

MOTTA, Vânia. Ideologia do capital social. Rio de Janeiro: eduerj, 2012.

PACHUKANIS, Euvegni. Teoria geral do direito e marxismo. Ed. Boitempo; 2017.

SILVA, José Adaumir da. A privatização de presídios: uma ressocialização perversa. Ed. Revan. Rio de Janeiro, 2016.

WACQUANT, Loïc. A nova gestão da miséria nos Estados Unidos. $3^{\text {a }}$ Ed. Rio de Janeiro: Revan, 2007.

ZAFFARONI, Eugênio Raúl. Em busca das penas perdidas. Rio de Janeiro, Revan. 2001. 


\section{Como referenciar este artigo}

VALENTIM, Vinicius Agueda. Presídio-empresa e encarceramento em massa: Uma denúncia ao atual regime de complexos industriais penais e a transformação da miséria em négocio. Rev. Sem Aspas, Araraquara, v.7, n.2, p. 194-218, jul./dez., 2018. ISSN: 2358-4238. DOI: 10.29373/sas.v7i2.11932

Submetido em: $20 / 11 / 2018$

Aprovado em: 10/02/2019 


\section{ANEXO}

\section{Gráfico I}

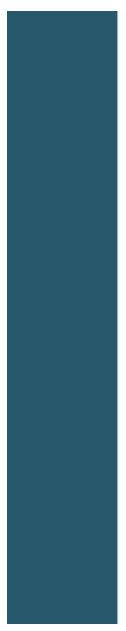

Gráfico 1. Evolução das pessoas privadas de liberdade entre 1990 e $2016^{12}$

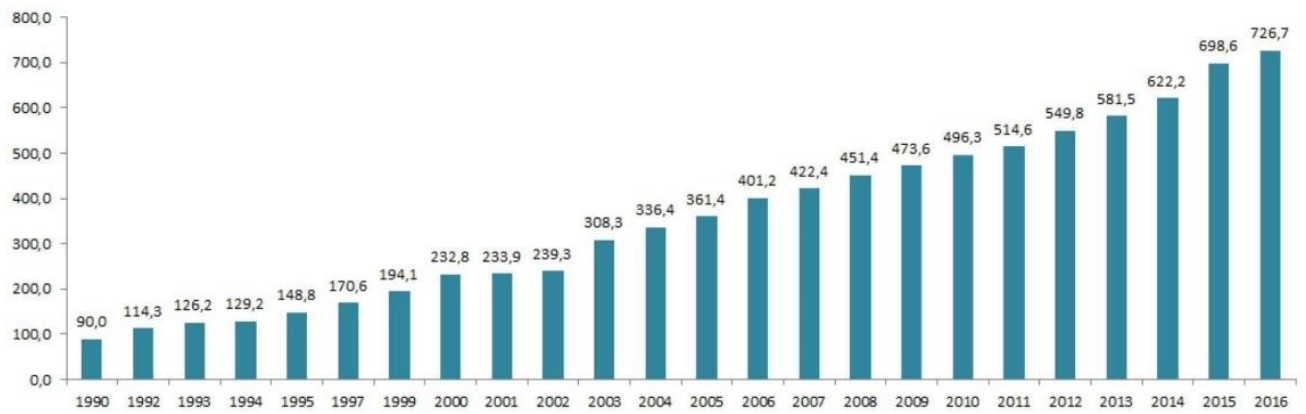

Fonte: Ministério da Justiça. A partir de 2005, dados do Infopen.

\section{Gráfico II}

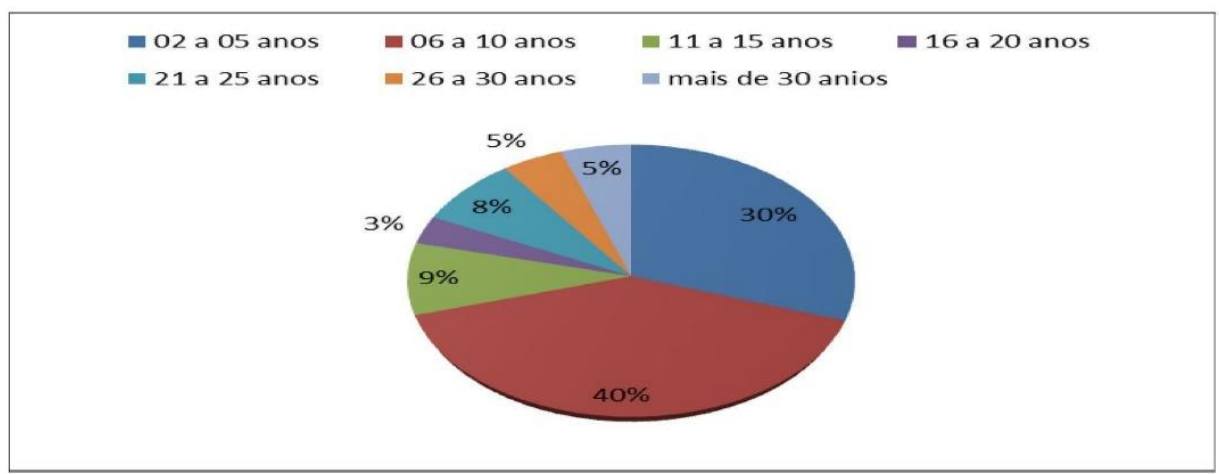

Gráfico 10 - Tempo de Pena dos apenados da unidade III do Complexo Prisional de Ribeirão das Neves - MG.

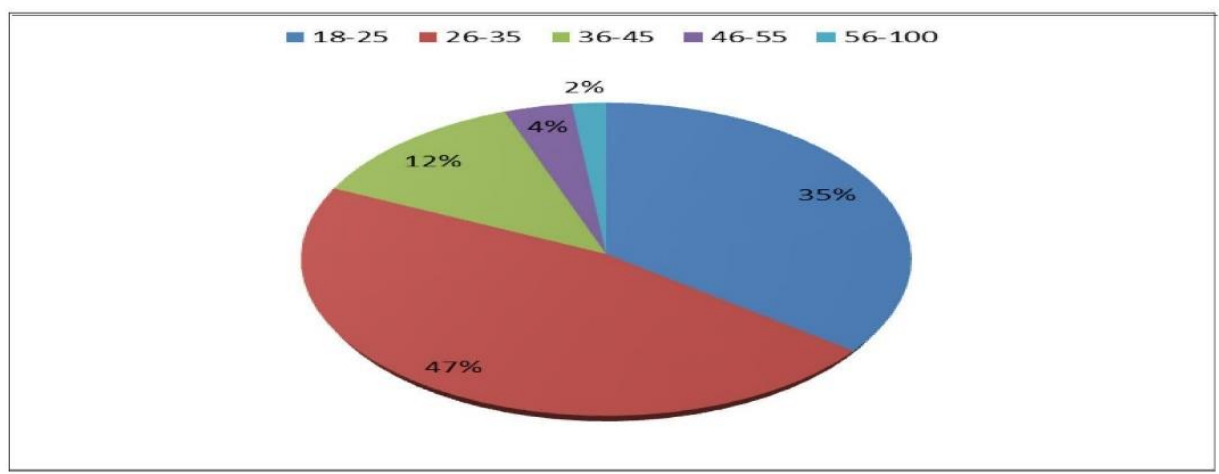

Gráfico 11 - Idade dos apenados da unidade III do Complexo Prisional de Ribeirão das Neves - MG.

Fonte: A privatização dos presídios: Uma ressocialização perversa. Rio de Janeiro. Ed. Revan, 2016. 


\section{Gráfico III}

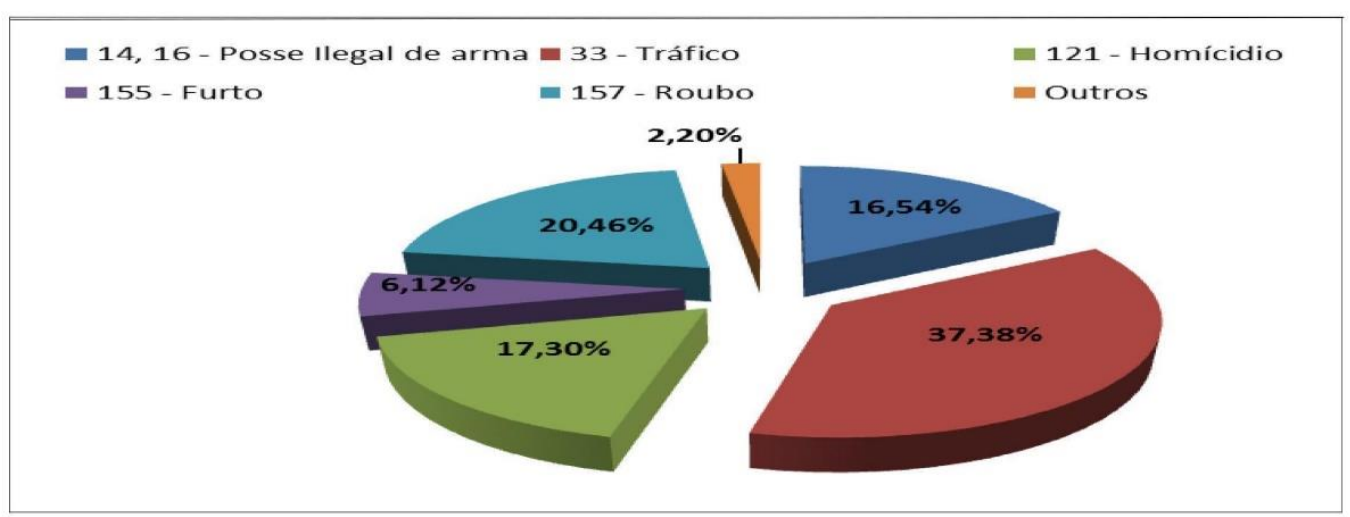

Gráfico 1 - Artigos do Código de Processo Penal pelos quais foram condenados os apenados da unidade I do Complexo Prisional de Ribeirão das Neves - MG.

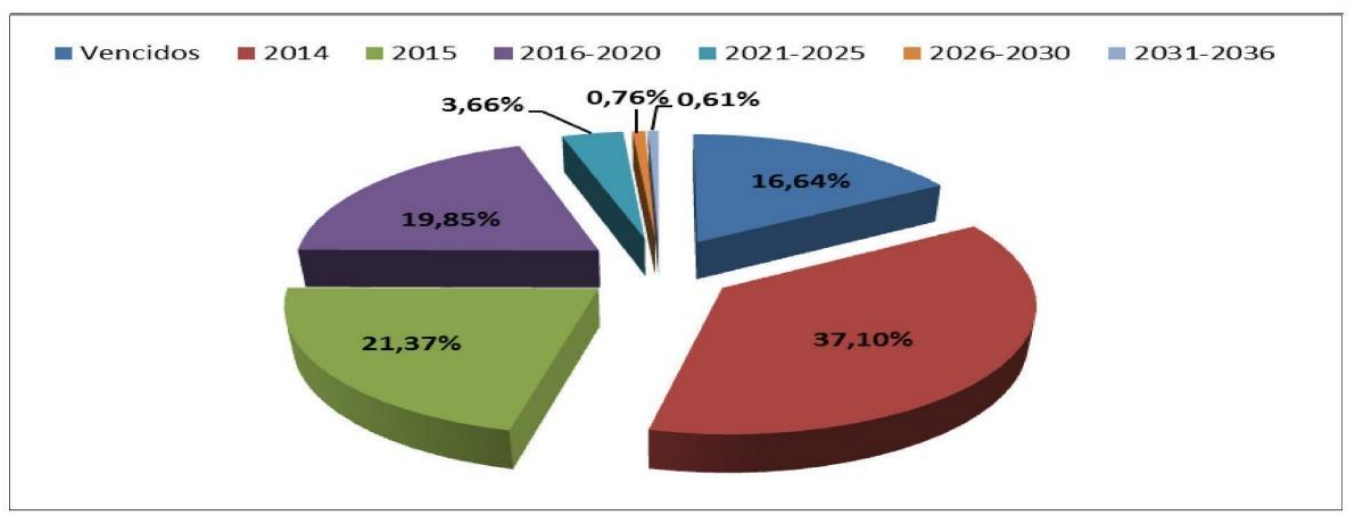

Gráfico 2 - Período em que os apenados da unidade I do Complexo Prisional de Ribeirão das Neves - MG progredirão para o regime semiaberto.

Fonte: A privatização dos presídios: Uma ressocialização perversa. Rio de Janeiro. Ed. Revan, 2016. 


\section{Gráfico IV}

ㅁ 01 ano - 05 anos 06 anos - 10 anos $=11$ anos -15 anos

- 16 anos - 20 anos 21 anos -30 anos $\mid$ Mais de 30 anos

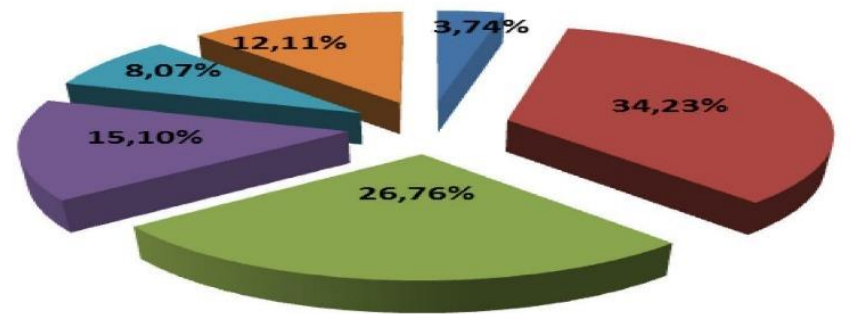

Gráfico 3 - Tempo de Pena dos apenados da unidade I do Complexo Prisional de Ribeirão das Neves - MG.

= 18- 25 anos $=26-35$ anos $=36-45$ anos $\mid 46-55$ anos $=56-100$

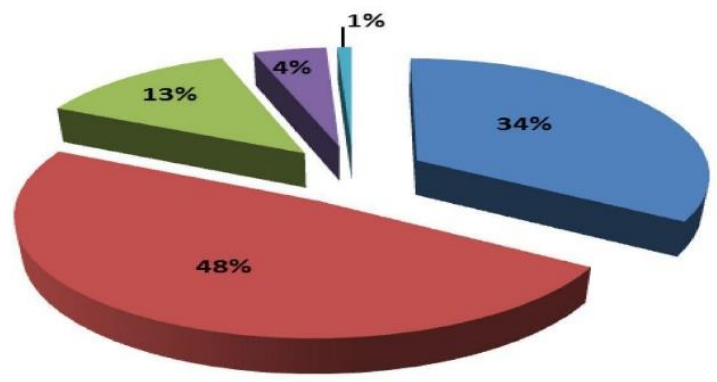

Gráfico 4 - Idade dos apenados da unidade I do Complexo Prisional de Ribeirão das Neves MG.

Fonte: A privatização dos presídios: Uma ressocialização perversa. Rio de Janeiro. Ed. Revan, 2016. 


\section{Gráfico V}

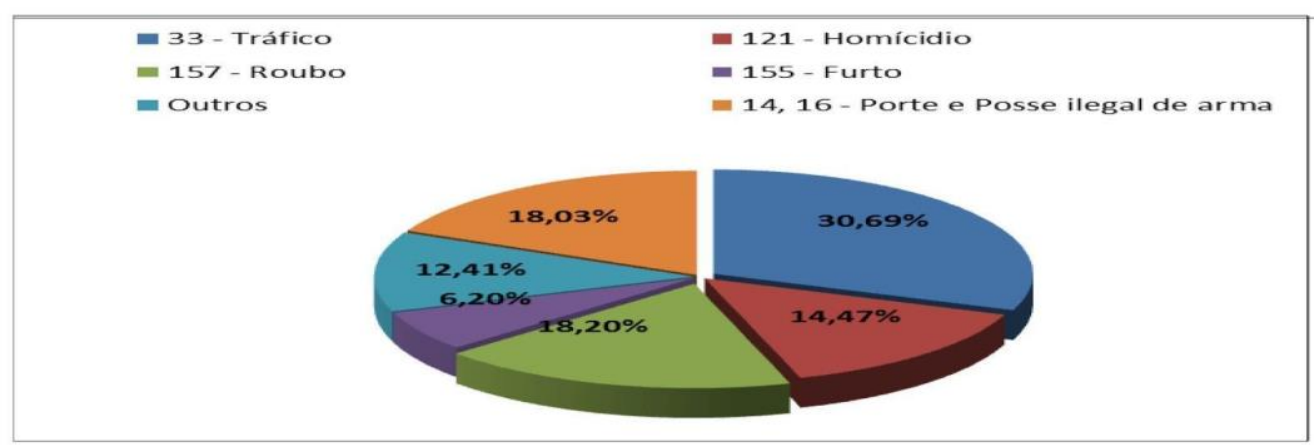

Gráfico 5 - Artigos do Código de Processo Penal pelos quais foram condenados os apenados da unidade II do Complexo Prisional de Ribeirão das Neves - MG.

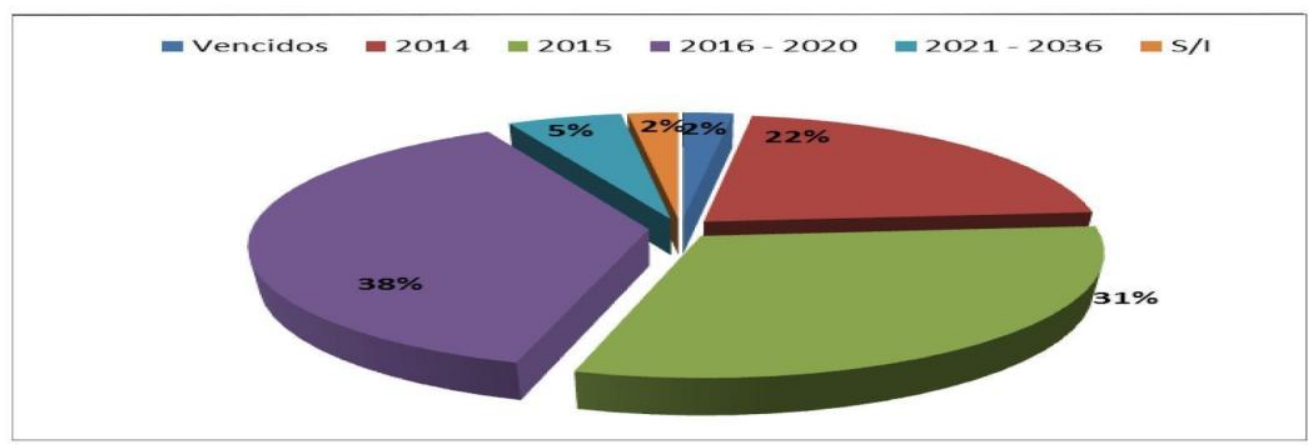

Gráfico 6 - Período em que os apenados da unidade II do Complexo Prisional de Ribeirão das Neves - MG progredirão para o regime semiaberto.

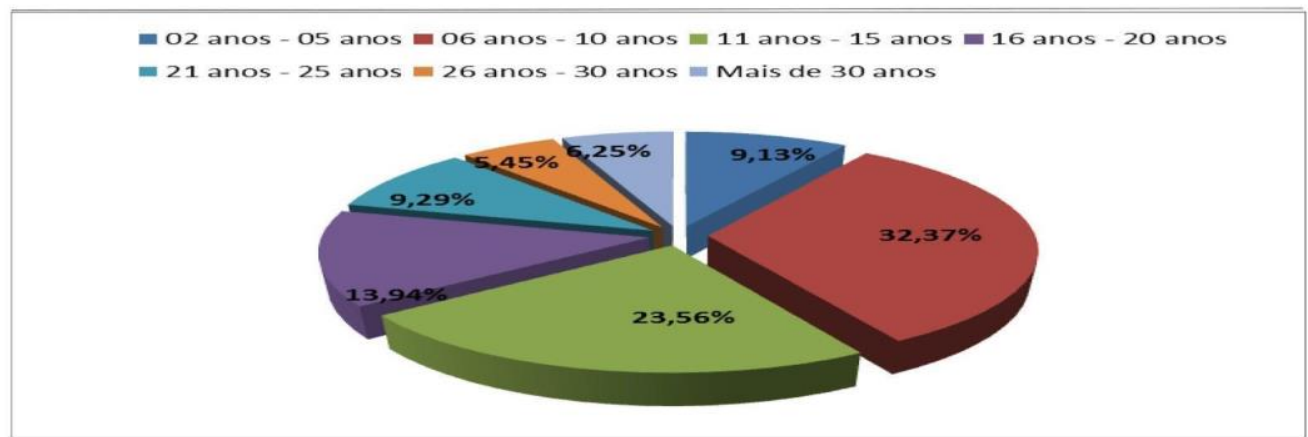

Gráfico 7 - Tempo de Pena dos apenados da unidade II do Complexo Prisional de Ribeirão das Neves - MG.

Fonte: A privatização dos presídios: Uma ressocialização perversa. Rio de Janeiro. Ed. Revan, 2016 